vival of the Park, which is of European interest. In the Western Pyrenees National Park (France), and peripheral areas, it is of the utmost importance that no further tourist facilities be built. Any exchange scheme allowing encroachments on the Park's territory in return for compensation in the peripheral zone is to be avoided.

In the Siebengebirge Nature Reserve (Federal Republic of Germany), the introduction of forest populations similar to those occurring naturally should be stipulated when management plans are revised. In the Kuscenneti National Park (Turkey), steps must be taken to ensure that the building of the Kocaçay dam does not affect the ecosystems of the lake and site, and to maintain the natural hydrological system of Lake Manyas with natural seasonal variations in water-levels. Lastly, in the Peak District National Park (United Kingdom), the legal vacuum which currently allows quarries to be reopened must be filled as quickly as possible. The plan to build a reservoir at Longdendale should be abandoned once and for all.

Hayo H. Hoefstra \& Françoise Tondre Naturopa Newsletter-Nature

European Centre for Nature Conservation BP 431 R6

67006 Strasbourg Cedex, France.

\title{
British Hedgehog Preservation Society
}

Spearheaded by the Nature Conservancy Council, everincreasing numbers of British people are becoming conscious of our natural heritage and of the importance of conserving all aspects of it, be they animal, vegetable, or mineral. There are hundreds of organizations whose members aim at conservatioin in one form or another, and one of these, although its impact has been national, is unique in that it originated in Shropshire. The British Hedgehog Preservatioin Society is based in the village of Knowbury, five miles $(8 \mathrm{~km})$ to the east of Ludlow, just off the A4117 road as it climbs up to the heights of Clee Hill.

The Society was founded in April 1982 by Major Adrian Coles, of Knowbury House, and followed his discovery of a Hedgehog (Erinaceus europaeus) that was unable to escape from the pit, beneath a cattle-grid, into which it had accidentally fallen. Such an incident highlighted the problem that when a Hedgehog (or other small mammal or bird) falls into a cattle- or sheep-grid, the near-vertical walls of the pit beneath the grid are too steep for the animal to climb out, and the result is death by dehydration or starvation. The solution is to provide a means of escape by installing, in a corner of the grid-pit, a ramp or slope up which the 'prisoner' can walk to freedom. This can be made of concrete, metal, or wood - with a rough surface to assist a firm foothold - and the cost is negligible.

Being a County Councillor, Major Coles was in a position to persuade Shropshire County Council Highways Department to install escape-ramps in grids within its authority, and, by publicizing this, to encourage other County Councils to follow suit. Press and other media reports aroused such interest that the Society was launched, with three declared aims of:

(1) Taking the necessary steps to secure the practical welfare of the Hedgehog by having escape-ramps installed in ALL cattle/sheep grids on public and private lands;

(2) Educating people-especially the younger generation - to appreciate and respect ALL our natural wildlife. particularly Hedgehogs; and

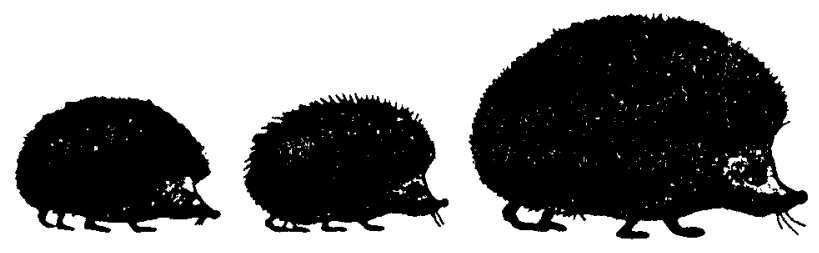

FIG. 1. Part of a family of Hedgehogs, of which the young usually number 4-8.

(3) Financing serious and much-needed research into the behavioural patterns of Hedgehogs.

Dr Patrick Morris, of the Department of Zoology, Royal Holloway College, London University, is an acknowledged expert on Hedgehogs, and is currently conducting investigations into the survival of that species in Britain. To date the Society has been able to provide $£ 4,000$ to help with this essential work, but much more money is needed. To help raise this and to cover ever-increasing costs, the Society has expanded its activities to include selling articles such as sweatshirts and tee shirts, ties, aprons, tea towels, ear studs, and other novelties, with a hedgehog motif-especially $\mathrm{Dr}$ Morris's own book, Hedgehogs.

The Society has a healthy and growing membership, and, as well as regularly circulating its own Newsletter, deals with many hundreds of queries from the public concerning the care of Hedgehogs, regularly releases material for the media, and collates information received concerning Hedgehog behaviour. Applications for membership should be addressed to the British Hedgehog Preservation Society at Knowbury House, Knowbury, Ludlow, Shropshire SY8 3JT, England (UK), enclosing a stamped self-addressed envelope.

\section{L.H.C. SHARP, Education Officer British Hedgehog Preservation Society Knowbury House Knowbury \\ Ludlow Shropsnire England, $U K$.}

\section{(Continued from page 268)}

It has been estimated that by the year 2000 , two-thirds of the world's total streamflow will be controlled by dams. At the world-scale, large dams are being completed at a rate of more than one per day ${ }^{\dagger}$ and river regulation schemes have destroyed very widely the integrity of the Catchment Ecobiomes and Ecosystems. Increasingly, long-distance water transfers from water-surplus catchments to water-deficient ones are becoming a serious alternative in water planning. The Ob Dam below the Irtysh confluence, for example, due for completion in AD 2010, is planned to divert impounded water south for $2,500 \mathrm{~km}$ in order to augment flows within the Amu-Darya River, and to provide irrigation supplies within Soviet central Asia and Kazakhstan. We may only guess at the consequences of such major engineering works on The Biosphere!

The WCB and the ISEE must direct themselves to safeguarding the World's natural rivers. Indeed, by directing attention to the progressive deterioration of the World's lotic ecosystems, we may convince this and future generations of the great urgency which exists for safeguarding our habitat, because it is only by managing our whole environment that we can hope to conserve our lotic ecosystems.

${ }^{\dagger}$ Petts, G.E. Impounded Rivers: Perspectives for Ecological Management. (Environmental Monographs \& Symposia, Gen. Ed. N. Polunin.) John Wiley \& Sons, Chichester-New York-Brisbane-Toronto-Singapore: xviii + 326, illustr., 1984.

GeofFrey E. PeTts, Lecturer Department of Geography University of Technology Loughborough

Leicestershire, England, $U K$. 